\title{
Efficacy of indigenous isolates of Beauveria bassiana (Balsamo) Vuillemin (Deuteromycota: Hyphomycetes) against the Colorado potato beetle, Leptinotarsa decemlineata (Say) (Coleoptera: Chrysomelidae)
}

\author{
Derya Baki ${ }^{1}$, Hilal Sule Tosun ${ }^{2}$ and Fedai Erler ${ }^{2^{*}}$
}

\begin{abstract}
Background: The Colorado potato beetle (CPB) Leptinotarsa decemlineata (Say) (Coleoptera: Chrysomelidae) is one of the most damaging pests of potatoes all over the world as well as in Turkey. Both adults and larvae of this pest feed on the foliage of potatoes, and often cause complete defoliation of potato plants, with considerable yield losses of up to $60 \%$. Chemical control of this pest has induced the selection of resistant CPB populations and negative environmental impact. The aim of the present study was to evaluate the pathogenicity of 14 Turkish isolates of Beauveria bassiana (Balsamo) Vuillemin (Deuteromycota: Hyphomycetes) against different stages of CPB under laboratory conditions.
\end{abstract}

Results: All isolates were tested as conidial suspensions of $\left(1 \times 10^{7}\right.$ conidia/ml), using spray method. The results from pathogenicity assays showed that virulence of tested isolates was variable, and mortality increased with the time of exposure. The highest mortality was seen in larvae of CPB; however, young larvae (1st and 2nd instars) were more susceptible to fungal isolates than older ones (3rd and 4th instars). Four isolates (BbDm-1, BbDs-2, BbMg-2, and BbMp-1) were more pathogenic than others against $\mathrm{L}$. decemlineata, causing mortalities between 96.7 and $100 \%$ in the 2 youngest larval instars, respectively, between 91.7 and $96.7 \%$ in the 2 oldest larval instars, respectively, and between 93.3 and $96.7 \%$ in 0-48-h-old adults, respectively, 9 days post treatment. Furthermore, these 4 isolates had the most potent egg-hatching inhibitory effects (66.7-90\%). The results of molecular phylogenetic analyses based on the ITS region sequence indicated that all tested B. bassiana isolates showed a high similarity (99\%) with other B. bassiana isolates in GenBank.

Conclusions: Results suggested that the 4 B. bassiana isolates were highly virulence and had the potential for biological control of CPB. Further tests under field conditions are recommended to validate the laboratory results.

Keywords: Entomopathogenic fungi, Beauveria bassiana, Biological control, Colorado potato beetle, Leptinotarsa decemlineata

\footnotetext{
*Correspondence: erler@akdeniz.edu.tr

${ }^{2}$ Faculty of Agriculture, Department of Plant Protection, Akdeniz University, 07070 Antalya, Turkey

Full list of author information is available at the end of the article
}

\section{Springer Open}

(c) The Author(s). 2021 Open Access This article is licensed under a Creative Commons Attribution 4.0 International License, which permits use, sharing, adaptation, distribution and reproduction in any medium or format, as long as you give appropriate credit to the original author(s) and the source, provide a link to the Creative Commons licence, and indicate if changes were made. The images or other third party material in this article are included in the article's Creative Commons licence, unless indicated otherwise in a credit line to the material. If material is not included in the article's Creative Commons licence and your intended use is not permitted by statutory regulation or exceeds the permitted use, you will need to obtain permission directly from the copyright holder. To view a copy of this licence, visit http://creativecommons.org/licenses/by/4.0/. 


\section{Background}

Potato (Solanum tuberosum L.) is a tuber crop belonging to the family Solanaceae. After wheat and rice, potato is the third largest crop in the world in terms of human consumption (FAOSTAT 2019). As a horticultural crop only, potato is the second most grown crop in Turkey after tomato. There are many insect pest species attacking potato crop and affect its production as well as quality in Turkey. One of the most damaging pests is the Colorado potato beetle (CPB), Leptinotarsa decemlineata (Say) (Coleoptera: Chrysomelidae). The pest is native to Mexico and was first described by Thomas Say in 1824 (Casagrande 1987). It spreads across most of the USA and was introduced into France in the 1920s from where it spread further reaching also parts of China (CABI 2017). In Turkey, the pest was detected for the first time in 1963 in Edirne (in the Thrace Region of Turkey), which borders with Bulgaria and Greece, and spread towards the inner regions of the country (Atak 1973). Adults and larvae of the pest feed on the foliage of potatoes and can cause complete defoliation of potato plants, with considerable yield losses of up to 60\% (Jacques and Fasulo 2015).

In Turkey, control of this pest is usually based on the use of synthetic insecticides. Some populations of the beetle have already developed a resistance to many groups of insecticides (Keskin and Yorulmaz-Salman 2020). As more insecticides are becoming ineffective due to resistance development or becoming phased out due to environmental concerns, the number of options available to potato growers dwindles. As an alternative method, biological control is often considered as the most environmentally friendly tool to control many pests. One of the main factors in biological control is the use of entomopathogenic fungi (EPF) (Mahr et al. 2008). Lately, attracting attention worldwide as a potential biological control agent for many insect pest species was noticed. The EPF Beauveria bassiana (Balsamo) Vuillemin (Deuteromycota: Hyphomycetes) is the most widely used fungal agent that has a potential to protect a range of crops (Goettel and Inglis 1997). Some previous studies have proved the potential effectiveness of $B$. bassiana against the insecticide resistant CPB strains (Roberts et al. 1981; Campbell et al. 1985).

The aim of the present study was to evaluate the efficacy of 14 indigenous isolates of $B$. bassiana isolated from cultivated and uncultivated soils in Antalya province, Turkey against different stages of $\mathrm{CPB}$ under laboratory conditions.

\section{Methods}

\section{Insect material and maintenance}

Insects used in the experiments were taken from a laboratory colony of $\mathrm{CPB}$ that originated with field- collected adults from potato production areas in Cameli (Denizli, Turkey). Rearing was carried out on the foliage of potted potato (S. tuberosum var. nahita) plants in a climate room set to $25 \pm 1^{\circ} \mathrm{C}, 60 \pm 5$ R.H., and 16:8 (L/D) hours photoperiod. Subsequent cultures were maintained in screen cages $(90 \times 90 \times 90 \mathrm{~cm})$ to obtain a fresh (known age) insect material. In the experiments, 0-48-h-old eggs and adults, young (1st and 2nd instars), and old (3rd and 4th instars) larvae of $L$. decemlineata were used. Young and old instars were selected based on their head capsule width and pronotum color (Niezgodzinski and Koroluk 1976; Boiteau and LeBlanc 1992).

\section{Indigenous $B$. bassiana isolates}

Fourteen $B$. bassiana isolates were used in this evaluation. Isolate names, sampling locations, isolation areas, and geographic coordinates are listed in Table 1.

\section{Viability of fungal isolates}

The viability of conidia of each fungal isolate was determined before any bioassay by the method described by Goettel and Inglis (1997). For this purpose, conidia of each fungal isolate were harvested from 3-week-old cultures with a sterile spatula and suspended in a $20-\mathrm{ml}$ sterile distilled water with a $0.03 \%$ Tween 80 and counted using a hemocytometer. Conidial suspensions $(1 \mathrm{ml})$ adjusted to $1 \times 10^{7}$ conidia/ml were spread on Petri dishes containing SDA (Sabouraud Dextrose Agar) medium. The dishes were then incubated in complete darkness at $25 \pm 2^{\circ} \mathrm{C}$ and examined after $24 \mathrm{~h}$. Percentage germination of conidia of each isolate was determined by counting the number of germinated conidia (a germ tube two times the diameter of the propagule) from 100 spores counted randomly on the surface area under the light microscope $(400 \times)$. Three replicate plates per isolate were used. The viability of all tested fungal isolates was above $95 \%$.

\section{Preparation of conidial suspension}

To determine the pathogenicity of indigenous $B$. bassiana isolates against $\mathrm{CPB}$, the experiments were carried out under the controlled conditions of $\left(25 \pm 2^{\circ} \mathrm{C}\right.$ and $65 \pm$ $5 \mathrm{RH}$ ). For this purpose, conidia from 2 to 3-week-old cultures of each fungal isolate, grown on PDA medium at $\left(25 \pm 2^{\circ} \mathrm{C}, 65 \pm 5 \mathrm{RH}\right)$, were collected by a sterile loop and suspended in a $20-\mathrm{ml}$ sterile distilled water with a $0.03 \%$ Tween 80 . Then, all suspensions were filtered through 4 layers of sterile cheesecloth in order to remove mycelium and agar pieces. Later, the conidial suspensions were vortexed for $3 \mathrm{~min}$ for homogenization. Conidial concentrations were determined using a hemocytometer and final concentration of each fungal isolate was adjusted to $1 \times 10^{7}$ conidia/ml (Fancelli et al. 2013). In all bioassays, all isolates were tested at a 
Table 1 Indigenous isolates of Beauveria bassiana used in the experiments

\begin{tabular}{|c|c|c|c|}
\hline Isolate name & Sampling site & Vegetation & Geographic coordinates \\
\hline $\mathrm{BbKm}-1$ & Kumluca/Antalya & Olive & $\mathrm{N} 36^{\circ} 19^{\prime} 17.1^{\prime \prime}$ E $30^{\circ} 20^{\prime} 23.0^{\prime \prime}$ \\
\hline BbKm-2 & Kumluca/Antalya & Orange & N 36 22' 18.8" E $30^{\circ} 16^{\prime} 29.1 "$ \\
\hline BbDm-1 & Demre/Antalya & Orange & N $36^{\circ} 14^{\prime} 39.7^{\prime \prime}$ E $29^{\circ} 58^{\prime} 45.0^{\prime \prime}$ \\
\hline BbFn-3 & Finike/Antalya & Orange & N $36^{\circ} 19^{\prime} 53.7^{\prime \prime}$ E $30^{\circ} 08^{\prime} 40.6^{\prime \prime}$ \\
\hline BbDs-2 & Döşemaltı/Antalya & Pomegranate & N $37^{\circ} 00^{\prime} 02.4^{\prime \prime}$ E $30^{\circ} 38^{\prime} 16.1 "$ \\
\hline BbAk-1 & Aksu/Antalya & Grassland & N $36^{\circ} 56^{\prime} 03.3^{\prime \prime}$ E $30^{\circ} 52^{\prime} 35.1 "$ \\
\hline $\mathrm{BbSr}-1$ & Serik/Antalya & Orange & N $36^{\circ} 55^{\prime} 33.8^{\prime \prime}$ E $31^{\circ} 07^{\prime} 20.7^{\prime \prime}$ \\
\hline $\mathrm{BbKr}-1$ & Kemer/Antalya & Forest & N 36 35' 51.0" E $30^{\circ} 33^{\prime} 22.7^{\prime \prime}$ \\
\hline BbKp-1 & Kepez/Antalya & Forest & N $36^{\circ} 54^{\prime} 50.4^{\prime \prime}$ E $30^{\circ} 37^{\prime} 48.4^{\prime \prime}$ \\
\hline BbMg-1 & Manavgat/Antalya & Olive & N $36^{\circ} 49^{\prime} 40.8^{\prime \prime}$ E $31^{\circ} 20^{\prime} 35.3^{\prime \prime}$ \\
\hline BbMg-2 & Manavgat/Antalya & Wheat & N $36^{\circ} 58^{\prime} 58.8^{\prime \prime}$ E $31^{\circ} 14^{\prime} 48.5^{\prime \prime}$ \\
\hline BbMp-1 & Muratpaşa/Antalya & Fig & N $36^{\circ} 53^{\prime} 07.2^{\prime \prime}$ E $30^{\circ} 44^{\prime} 30.4^{\prime \prime}$ \\
\hline BbGp-1 & Gazipaşa/Antalya & Forest & N $36^{\circ} 12^{\prime} 52.0^{\prime \prime}$ E $32^{\circ} 23^{\prime} 45.0^{\prime \prime}$ \\
\hline $\mathrm{BbKl}-1$ & Korkuteli/Antalya & Pear & N $37^{\circ} 03^{\prime} 21.3^{\prime \prime}$ E $30^{\circ} 10^{\prime} 33.8^{\prime \prime}$ \\
\hline
\end{tabular}

conidial suspension of $1 \times 10^{7}$ conidia/ml using the spray method.

\section{Experimental bioassays}

\section{Bioassay against $L$. decemlineata eggs}

This experiment was conducted, using $\mathrm{CPB}$ egg masses (0-48-h-old eggs) on potato leaves. The egg masses were treated in 3 replications (10 eggs each) with one of the tested $B$. bassiana isolates through direct spray, using a handheld sprayer with a tank capacity of 0.51 . However, separate sprayers were used for each fungal isolate to prevent cross-contamination. The control group was treated by distilled water $+0.03 \%$ Tween 80 . Treated eggs were then removed and placed in clean Petri dishes (9 $\mathrm{cm}$ in diameter) at $25 \pm 2^{\circ} \mathrm{C}$ and $65 \pm 5 \mathrm{RH}$ till egg hatching. Each Petri dish was counted as one replicate. All egg masses were checked daily for hatching and a small potato leaf was placed within each Petri dish as food for the larvae when hatching day approached. Number of hatched larvae was recorded to determine a percentage of hatching for each replicate within a treatment. During data collection, infected (unhatched) eggs conspicuously shrunk, usually turned orange-brown and had more or less fungal outgrowths (with a white fuzzy appearance) on the surface, that could be easily distinguished from those killed by factor(s) that had a shriveled and light brownish appearance, were counted as dead and included in the count. Moreover, the rate of mortality in surviving 1st instar larvae was also recorded for each replicate within a treatment. After hatching, 1st instar larvae were then reared under the abovementioned conditions on clean potato leaves until developed to the 2nd instar. This procedure allowed detecting latent effect of the exposure of egg masses to the tested $B$. bassiana isolates on 1st instar larvae.

\section{Bioassay against $L$. decemlineata larvae}

Larval bioassay was conducted using young (1st and 2nd instars) and old (3rd and 4th instars) larvae of CPB. Each treatment, using spray method, was replicated 3 times with 10 larvae each. For each treatment, 10 young (five 1st and five 2nd instars) or 10 old (five 3rd and five 4th instars) larvae were placed in each Petri dish $(9 \mathrm{~cm}$ in diameter) lined with 3 layers of filter paper, and they were then sprayed from 30-cm distance with a handheld sprayer, using $2.0 \mathrm{ml}$ of conidial suspension of any fungal isolate. The control group was treated by sterile distilled water $+0.03 \%$ Tween 80 . After air drying, the treated larvae were carefully transferred to new Petri dishes containing clean potato leaves using a fine camelhair brush. The lid of each Petri dish was closed and perforated 20 times using a hot needle for ventilation. All dishes were kept under the abovementioned laboratory conditions. Surviving larvae were fed on untreated leaves for the rest of the experimental period. To record mortality, Petri dishes were daily examined, and mortality rates were recorded $3,5,7$, and 9 days after treatment. At each observation, larvae were touched using a fine-forceps and if the insect did not move, it was recorded as dead. To assess the growth of fungal mycelium on the insects, which would indicate insect mortality caused by the EPF agents, all dead larvae were removed from the dishes and placed in new dishes lined with moistened filter paper, incubated at $25 \pm 2^{\circ} \mathrm{C}$ and $65 \pm 5$ $\mathrm{RH}$ in complete darkness, and evaluated for up to 14 days under a stereomicroscope to observe fungal growth 
on larval cadavers. Dead larvae showed no fungal outgrowths of similar characteristics of the treated ones were excluded.

\section{Bioassay against $L$. decemlineata adults}

The bioassay was conducted using 0-48-h-old adults of $L$. decemlineata. Adult $\mathrm{CPB}$ was treated by each of $B$. bassiana isolates as previously mentioned in larval bioassay. Each treatment was replicated 3 times (10 adults each). The control group was treated by sterile distilled water $+0.03 \%$ Tween 80 . Treated adults (10 per dish) were transferred into new Petri dishes containing fresh potato foliage. The dishes were then closed and kept under the aforementioned laboratory conditions. Treatments were checked at daily basis and the rate of adult mortality was recorded $3,5,7$, and 9 days post treatment. Final mortality counts were performed using the same procedure mentioned in larval mortality counts.

\section{Phylogenetic placement of tested B. bassiana isolates}

Genomic DNA of tested B. bassiana isolates were extracted, following the modified $\mathrm{CTAB}$ method described by Doyle and Doyle (1990). The PCR was performed in a Thermal Cycler by using two different primers based on ITS-rDNA region gene sequences, which included, ITS1 (5' -TCCGTAGGTGAACCTGCGG-3') and ITS4 (5'-TCCTCCGCTTATTGATATGC-3') (White et al. 1990). Each PCR reaction was conducted in a final volume of $50.0 \mu \mathrm{l}$ containing $3.0 \mu \mathrm{l} 2.5 \mathrm{mM} \mathrm{MgCl} 2,5.0 \mu \mathrm{l}$ 10× Taq buffer with KCI, $8.0 \mu \mathrm{l} 100 \mathrm{mM}$ dNTPs, $0.25 \mu \mathrm{l}$ 5 U $\mu$ l-1 Taq-DNA polymerase (Thermo Fisher Scientific, Waltham, MA, USA), $1 \mu \mathrm{l}$ of each primer, $27.8 \mu \mathrm{l}$ sterile $\mathrm{dd}_{2} \mathrm{O}$, and $4.0 \mu \mathrm{l}$ fungal DNA suspension. The cycling conditions included an initial denaturation for 60 $\mathrm{s}$ at $95^{\circ} \mathrm{C}$, followed by 35 cycles of $60 \mathrm{~s}$ at $94^{\circ} \mathrm{C}, 120 \mathrm{~s}$ at $58^{\circ} \mathrm{C}, 60 \mathrm{~s}$ at $72^{\circ} \mathrm{C}$, and a final extension $300 \mathrm{~s}$ at $72^{\circ} \mathrm{C}$. The amplified PCR products $(10 \mu \mathrm{l})$ and $1 \mathrm{~kb}$ DNA Ladder (Thermo Fisher Scientific) were separated by gel electrophoresis in $1 \%$ agarose gel in $0.5 \times$ TAE $(\mathrm{dH} 2 \mathrm{O}$ $1000 \mathrm{ml}$, Tris-Base $4.84 \mathrm{~g}$, glacial acetic acid $1.02 \mathrm{ml}, 0.5$ M. EDTA (pH: 8.0) $2 \mathrm{ml}$ ) buffer after staining with jel red $(1 \mathrm{mg} / \mathrm{l})$ and run at $80 \mathrm{~V} / \mathrm{cm}$ for $90 \mathrm{~min}$. The gel was then visualized with an ultraviolet light imaging system (Vilber Lourmat SR 12575 UV transilluminator, France). The amplified PCR products were sequenced using the ABI 3730XL Sanger sequencing device (Applied Biosystems, Foster City, CA) and the BigDye Terminator v3.1 Cycle Sequencing Kit (Applied Biosystems, Foster City, CA) in the Macrogen Netherlands laboratory. The DNA sequences of isolates were performed using the ClustalW algorithm in the Bioedit program (Thompson et al. 1994; Hall 1999). The nucleotide sequence of tested isolates was compared with that of the other isolates of the related species using a Blast
Bioinformatics search of sequences from the National Center for Biotechnology Information (NCBI) GenBank (Altschul et al. 1997).

Molecular phylogenetic analyses were conducted with MEGA5 software (Biodesign Institute, Tempe, Arizona) using the maximum likelihood method based on the Tamura 3-parameter model (Kimura 1980; Tamura et al. 2011). The phylogenetic analysis was done based on the ITS region sequence of tested isolates and the nucleotide sequence of the other fungi retrieved from GenBank, the accession numbers of which are presented in Table 6 .

\section{Statistical analysis}

In larval and adult bioassays, no control mortality was observed; therefore, no correction was necessary for the mortality data. All values were arcsine transformed prior to analysis. Data were then analyzed by one-way ANOVA using the general linear model of the SPSS 23.0 Windows (IBM Corp. 2015, New York, USA). Differences among the treatment means were compared using the Tukey's HSD test at a significance level of $P<0.05$.

\section{Results}

Effectiveness of tested $B$. bassiana isolates against $L$. decemlineata eggs

Data presented in Table 2 showed that the tested $B$. bassiana isolates generally had low pathogenic activity against $0-48$-h-old eggs. There were significant differences among some of the $B$. bassiana isolates tested at 1 $\times 10^{7}$ conidia $/ \mathrm{ml}$ in terms of hatching rate of $L$. decemlineata eggs $(P<0.05)$. The lowest hatching rate $(6.7 \%)$ was recorded in eggs treated with isolate $\mathrm{BbMg}-2$, which showed the most potent egg-hatching inhibitory effect (93.3\%) (Table 2). This isolate was followed the most strongly by the isolates BbMp- 1 , BbDs- 2 , and BbDm- 1 , all the three of which exhibited the same rate of inhibitory effect (90\%). The lowest inhibitory effect $(6.7 \%)$ was exhibited by isolate $\mathrm{BbKm}-2$, recording (93.3\%) hatching rate in eggs.

For the mortality rates of the fed 1st instar larvae during molting to 2nd instar (usually 4 days), there were significant differences among some of the isolates tested $(P<0.05)$. The highest mortality rate $(63.3 \%)$ in 1 st instar larvae hatched from the eggs treated with B. bassiana was caused by the isolates BbDs- 2 and BbMp- 1 . These 2 isolates were followed most strongly by the isolates $\mathrm{BbMg}-2$ and $\mathrm{BbDm}-1$, both of which exhibited the same rate of mortality $(60 \%)$.

\section{Effectiveness of tested B. bassiana isolates against $L$. decemlineata larvae}

All tested $B$. bassiana isolates at $1 \times 10^{7}$ conidia/ml showed pathogenic activity against both young (1st and 2nd instars) and old (3rd and 4th instars) larvae of $L$. 
Table 2 Egg-hatching rates of Leptinotarsa decemlineata eggs treated with fourteen indigenous Beauveria bassiana isolates, egghatching inhibitory effects of tested fungal isolates, and mortality rates of fed 1st larval instar during molting to 2nd instar

\begin{tabular}{|c|c|c|c|}
\hline Isolate name & Egg-hatching (\%) & Inhibition of egg-hatching (\%) & First instar mortality (\%) \\
\hline BbKm-1 & $70.0 \pm 0.0^{b c^{* *}}$ & 30.0 & $20.0 \pm 0.0^{d}$ \\
\hline $\mathrm{BbKm}-2$ & $93.3 \pm 3.3^{\mathrm{a}}$ & 6.7 & $6.7 \pm 3.3^{f}$ \\
\hline BbDm-1 & $10.0 \pm 0.0^{\mathrm{e}}$ & 90.0 & $60.0 \pm 0.0^{\mathrm{a}}$ \\
\hline $\mathrm{BbFn-3}$ & $66.7 \pm 3.3^{b c}$ & 33.3 & $23.3 \pm 3.3^{\mathrm{cd}}$ \\
\hline BbKp-1 & $43.3 \pm 3.3^{d}$ & 56.7 & $40.0 \pm 0.0^{b}$ \\
\hline BbAk-1 & $80.0 \pm 0.0^{\mathrm{ab}}$ & 20.0 & $10.0 \pm 0.0^{\mathrm{ef}}$ \\
\hline $\mathrm{BbSr}-1$ & $76.7 \pm 6.7^{b}$ & 23.3 & $16.7 \pm 3.3^{\mathrm{e}}$ \\
\hline BbKr-1 & $60.0 \pm 5.8^{c}$ & 40.0 & $33.3 \pm 3.3^{b c}$ \\
\hline BbDs-2 & $10.0 \pm 0.0^{\mathrm{e}}$ & 90.0 & $63.3 \pm 3.3^{\mathrm{a}}$ \\
\hline BbMg-1 & $60.0 \pm 0.0^{c}$ & 40.0 & $30.0 \pm 0.0^{c}$ \\
\hline BbMg-2 & $6.7 \pm 3.3^{e}$ & 93.3 & $60.0 \pm 5.8^{\mathrm{a}}$ \\
\hline BbMp-1 & $10.0 \pm 0.0^{\mathrm{e}}$ & 90.0 & $63.3 \pm 3.3^{\mathrm{a}}$ \\
\hline BbGp-1 & $43.3 \pm 3.3^{d}$ & 56.7 & $40.0 \pm 0.0^{b}$ \\
\hline $\mathrm{BbKl}-1$ & $66.7 \pm 3.3^{b c}$ & 33.3 & $26.7 \pm 3.3^{c}$ \\
\hline$d f$ & 41 & - & 41 \\
\hline$F$ & 85.0 & - & 49.7 \\
\hline P & 0.000 & - & 0.000 \\
\hline
\end{tabular}

*In a single-dose trial, all the isolates were tested at a concentration of $1 \times 10^{7}$ conidia $/ \mathrm{ml}$

**Means in a column followed by the same letter are not significantly different (Tukey's HSD test; $P<0.05$ )

decemlineata. Mortality rates decreased with increasing age of $L$. decemlineata larvae but increased with the elapsed time after treatment (Tables 3 and 4). There were significant differences among the tested B. bassiana isolates in their mortality rates in young larvae $3,5,7$, and 9 days after treatment $(P<0.05)$ (Table 3). Based on the mortality rates of young larvae on the 9th day, 4 isolates (BbMp-1, BbMg-2, BbDm-1, and BbDs-2) of the 14 $B$. bassiana isolates tested were more virulent than others, and caused 100, 100, 98.3, and 96.7\% mortalities, respectively. On the 3rd and 5th days of treatment, the highest mortality (53.3 and $85 \%$, respectively) was exhibited by the isolate, BbKl-1; however, efficacy of this isolate remained stable on the 7th and 9th days. As for the oldest larvae, data presented in Table 4 indicated that mortality rate increased with the elapsed time after treatment. As in the young larvae, 4 isolates (BbMp-1, $\mathrm{BbMg}-2, \mathrm{BbDm}-1$, and BbDs-2) were significantly more pathogenic than others against the oldest larvae and exhibited 96.7, 93.3, 95.0, and 91.7\% mortalities, respectively, 9 day post treatment $(P<0.05)$.

\section{Effectiveness of tested $B$. bassiana isolates against $L$. decemlineata adults}

As shown in Table 5, all tested B. bassiana isolates had different efficacy rates against $0-48$-h-old adults of $L$. decemlineata. Mortality was isolate- and elapsed timedependent, and differences in mortality at each count date were generally significant among the different isolates tested $(P<0.05)$. As in the larvae of $L$. decemlineata, 4 isolates (BbMp- $1, \mathrm{BbMg}-2, \mathrm{BbDm}-1$, and BbDs2) were significantly more virulent than the others against $L$. decemlineata adults $(P<0.05)$. Of these 4 isolates, BbDs- 2 caused the highest adult mortality by 96.7\%. The remaining 3 isolates had the same mortality rate (93.3\%) 9 day post treatment. Isolates BbFn-3 and BbAk-1 caused the lowest adult mortalities (0 and 3.3\% on the 3rd and 5th days of treatment, respectively) that were non-significantly different from each other $(P<$ $0.05)$.

\section{Phylogenetic placement of tested $B$. bassiana isolates}

The DNA sequences of the tested B. bassiana isolates were loaded into GenBank, and their accession numbers were obtained and used for comparison in phylogenetic analysis. The accession numbers of the isolates are presented in Table 6. After alignment, the ITS region sequence data set consisted of 487 aligned positions for Beauveria isolates. All the B. bassiana isolates from Turkey and GenBank were clustered together. All the $B$. bassiana isolates tested had $99 \%$ evolutionary homology with other B. bassiana isolates from the NCBI (Fig. 1).

\section{Discussion}

The present study demonstrated that some of the tested indigenous isolates of $B$. bassiana can be used for the 
Table 3 Percentage mortalities of young larvae (1st and 2nd instars) of Leptinotarsa decemlineata in response to the tested Beauveria bassiana isolates at 3, 5, 7, and 9 days after treatment under laboratory conditions

\begin{tabular}{|c|c|c|c|c|c|c|c|}
\hline \multirow{2}{*}{$\begin{array}{l}\text { Isolate } \\
\text { name }\end{array}$} & \multicolumn{4}{|c|}{ Percent mortality $( \pm \mathrm{SE})$ from a single-dose trial ${ }^{*}$} & \multirow[t]{2}{*}{ df } & \multirow[t]{2}{*}{$F$} & \multirow[t]{2}{*}{$P$} \\
\hline & 3 days & 5 days & 7 days & 9 days & & & \\
\hline BbKm-1 & $8.3 \pm 1.7^{\mathrm{cdC}^{* *}}$ & $30.0 \pm 5.7^{\mathrm{efB}}$ & $41.7 \pm 1.7^{\text {deAB }}$ & $56.7 \pm 6.7^{\mathrm{CA}}$ & 11 & 20.0 & 0.000 \\
\hline $\mathrm{BbKm}-2$ & $0.0 \pm 0.0^{\mathrm{dC}}$ & $15.0 \pm 5.0^{\mathrm{fBC}}$ & $26.7 \pm 6.7^{\mathrm{eB}}$ & $53.3 \pm 3.3^{\mathrm{cA}}$ & 11 & 25.2 & 0.000 \\
\hline $\mathrm{BbDm}-1$ & $46.7 \pm 4.4^{\mathrm{abc}}$ & $78.3 \pm 4.4^{\mathrm{abcB}}$ & $95.0 \pm 5.0^{\mathrm{aAB}}$ & $98.3 \pm 1.7^{\mathrm{aA}}$ & 11 & 33.4 & 0.000 \\
\hline BbFn-3 & $6.7 \pm 4.4^{\mathrm{dB}}$ & $25.0 \pm 8.7^{f B}$ & $61.7 \pm 6.0^{\mathrm{cdA}}$ & $70.0 \pm 5.0^{\mathrm{bcA}}$ & 11 & 23.2 & 0.000 \\
\hline BbKp-1 & $3.3 \pm 3.3^{\mathrm{dc}}$ & $53.3 \pm 3.3^{\mathrm{deB}}$ & $88.3 \pm 6.0^{\mathrm{abA}}$ & $91.7 \pm 8.9^{\mathrm{abA}}$ & 11 & 52.8 & 0.000 \\
\hline BbAk-1 & $0.0 \pm 0.0^{d C}$ & $13.3 \pm 3.3^{\mathrm{fBC}}$ & $30.0 \pm 5.0^{\mathrm{eAB}}$ & $46.7 \pm 6.0^{C A}$ & 11 & 22.7 & 0.000 \\
\hline $\mathrm{BbSr}-1$ & $30.0 \pm 2.9^{\mathrm{bcB}}$ & $81.7 \pm 1.7^{\mathrm{abA}}$ & $85.0 \pm 2.9^{\mathrm{abA}}$ & $86.7 \pm 3.3^{\mathrm{abA}}$ & 11 & 97.6 & 0.000 \\
\hline BbKr-1 & $48.3 \pm 1.7^{\mathrm{abB}}$ & $58.3 \pm 4.4^{\mathrm{bcd} A B}$ & $80.0 \pm 7.6^{\mathrm{abcA}}$ & $85.0 \pm 7.6^{\mathrm{abA}}$ & 11 & 13.7 & 0.002 \\
\hline BbDs-2 & $50.0 \pm 5.0^{\mathrm{abc}}$ & $78.3 \pm 1.7^{\mathrm{abcB}}$ & $83.3 \pm 3.3^{\mathrm{abc} A B}$ & $96.7 \pm 1.7^{\mathrm{aA}}$ & 11 & 37.0 & 0.000 \\
\hline BbMg-1 & $36.7 \pm 10.1^{\mathrm{abB}}$ & $58.3 \pm 4.4^{\mathrm{bcd} A \mathrm{~B}}$ & $71.7 \pm 6.0^{\mathrm{bca}}$ & $86.7 \pm 3.3^{\mathrm{abA}}$ & 11 & 10.7 & 0.004 \\
\hline BbMg-2 & $46.7 \pm 3.3^{\mathrm{abc}}$ & $56.7 \pm 1.7^{\mathrm{cdC}}$ & $75.0 \pm 2.9^{\mathrm{abcB}}$ & $100.0 \pm 00^{\mathrm{aA}}$ & 11 & 98.8 & 0.000 \\
\hline BbMp-1 & $38.3 \pm 1.7^{\mathrm{abD}}$ & $78.3 \pm 1.7^{\mathrm{abcc}}$ & $91.7 \pm 1.7^{\mathrm{abB}}$ & $100.0 \pm 00^{\mathrm{aA}}$ & 11 & 358.6 & 0.000 \\
\hline BbGp-1 & $5.0 \pm 2.9^{d C}$ & $50.0 \pm 7.6^{\mathrm{deB}}$ & $71.7 \pm 1.7^{\mathrm{bcA}}$ & $86.7 \pm 4.4^{\mathrm{abA}}$ & 11 & 57.0 & 0.000 \\
\hline BbKl-1 & $53.3 \pm 6.7^{\mathrm{aB}}$ & $85.0 \pm 2.9^{\mathrm{aA}}$ & $88.3 \pm 6.0^{\mathrm{abA}}$ & $88.3 \pm 6.0^{\mathrm{abA}}$ & 11 & 9.3 & 0.006 \\
\hline$d f$ & 41 & 41 & 41 & 41 & & & \\
\hline $\mathrm{F}$ & 23.0 & 30.5 & 25.4 & 15.3 & & & \\
\hline$P$ & 0.000 & 0.000 & 0.000 & 0.000 & & & \\
\hline
\end{tabular}

*In a single-dose trial, all the isolates were tested at a concentration of $1 \times 10^{7}$ conidia $/ \mathrm{ml}$

**Means in a column followed by the same lower-case letter are not significantly different, and means in a row followed by the same upper-case letter are not significantly different (Tukey's HSD test; $P<0.05$ )

management of CPB. However, successive subcultures of indigenous $B$. bassiana isolates on solid media differed significantly in their virulence. Moreover, different stages of $\mathrm{CPB}$ had different susceptibilities to the isolates tested. Eggs were not so much susceptible to infection. Adults showed susceptibility much lower than larvae. In larval bioassay, the tested $B$. bassiana isolates significantly differed in their pathogenicity to $L$. decemlineata larval instars. High mortality was obtained in younger larvae than the oldest ones. The findings of this research are in accordance with the previous studies that compared efficacy of different $B$. bassiana isolates on different stages of CPB (Ignoffo et al. 1983; Watt and LeBrun 1984; Fargues 1991; Long et al. 1998).

A review of the related literature indicated that $B$. bassiana isolates obtained from different parts of the world varied in their pathogenic activity against different stages of $\mathrm{CPB}$, and there was a high variability among the fungal isolates in terms of mortality rates. For instance, Timonin (1939) tested the efficacy of B. bassiana against $L$. decemlineata eggs and newly hatched larvae and reported that there was no effect of B. bassiana on egg mortality, but he observed 1st instar mortality on the 4th day after egg hatch. He also reported that 1st instar mortality was due to ingestion of fresh spores still on the egg chorion by the larvae. In a similar study,
Long et al. (1998) evaluated effects of the B. bassianabased commercial product (Mycotrol ${ }^{\circ}$, Mycotech Corporation, Butte, Montana) at 5 concentrations (ranging from $1 \times 10^{4}$ to $1 \times 10^{8}$ conidia $/ \mathrm{ml}$ ) on egg hatching and subsequent 1 st instar larval survival of $L$. decemlineata by spraying egg masses on potato leaves. They reported that there was no effect of B. bassiana on egg and 1st instar mortality, even at the highest concentration. Obtained findings on 1st instar mortality are in accordance with those of Timonin (1939), but in contrast with those of Long et al. (1998). In another study, Todorova et al. (2000) evaluated 10 isolates of B. bassiana from different sources and geographical sites under laboratory conditions at a concentration of $1 \times 10^{7}$ conidia/ml for their pathogenicity against adults of $L$. decemlineata and reported that 6 isolates were highly virulent and caused mortalities ranging from 86.7 to $100 \%$ by 8 day posttreatment. In a more recent study, Ozturk et al. (2015) tested pathogenicity of 3 local $B$. bassiana isolates at $1 \times$ $10^{8}$ conidia/ml, using spray method against different stages of $L$. decemlineata in Isparta province of Turkey and reported that tested isolates caused mortalities between 57.1 and $100 \%$ in young (2nd and 3rd instars) larvae, between 36.7 and $100 \%$ in old (4th instar) larvae, and between 23.3 and $86.2 \%$ in 1-week adults; 3 and 7 days post treatment. As well, obtained results on adult 
Table 4 Percentage mortalities of old larvae (3rd and 4th instars) of Leptinotarsa decemlineata in response to the tested Beauveria bassiana isolates at 3, 5, 7, and 9 days after treatment under laboratory conditions

\begin{tabular}{|c|c|c|c|c|c|c|c|}
\hline \multirow{2}{*}{$\begin{array}{l}\text { Isolate } \\
\text { name }\end{array}$} & \multicolumn{4}{|c|}{ Percent mortality $( \pm \mathrm{SE})$ from a single-dose trial ${ }^{*}$} & \multirow[t]{2}{*}{ df } & \multirow[t]{2}{*}{$F$} & \multirow[t]{2}{*}{$P$} \\
\hline & 3 days & 5 days & 7 days & 9 days & & & \\
\hline BbKm-1 & $3.3 \pm 3.3^{\mathrm{dec} * *}$ & $15.0 \pm 2.9^{\mathrm{cdBC}}$ & $26.7 \pm 3.3^{\text {cdeB }}$ & $50.0 \pm 2.9^{\operatorname{def} A}$ & 11.0 & 40.8 & 0.000 \\
\hline BbKm-2 & $3.3 \pm 1.7^{\mathrm{dec}}$ & $11.7 \pm 1.7^{\mathrm{dBC}}$ & $20.0 \pm 2.9^{e B}$ & $45.0 \pm 2.9^{\mathrm{efA}}$ & 11.0 & 58.3 & 0.000 \\
\hline BbDm-1 & $18.3 \pm 1.7^{\mathrm{abcdc}}$ & $45.0 \pm 2.9^{\mathrm{aB}}$ & $61.7 \pm 6.0^{\mathrm{abB}}$ & $95.0 \pm 2.9^{\mathrm{aA}}$ & 11.0 & 74.1 & 0.000 \\
\hline $\mathrm{BbFn-3}$ & $0.0 \pm 0.0^{\mathrm{eB}}$ & $10.0 \pm 2.9^{\mathrm{dB}}$ & $41.7 \pm 3.3^{\text {abcdeA }}$ & $51.7 \pm 1.7^{\text {cdefA }}$ & 11.0 & 110.2 & 0.000 \\
\hline BbKp-1 & $1.7 \pm 1.7^{\mathrm{dec}}$ & $21.7 \pm 4.4^{\mathrm{bcdB}}$ & $53.3 \pm 1.7^{\mathrm{abcA}}$ & $61.7 \pm 4.4^{\text {cdeA }}$ & 11.0 & 70.1 & 0.000 \\
\hline BbAk-1 & $3.3 \pm 3.3^{\mathrm{deB}}$ & $8.3 \pm 1.7^{\mathrm{dB}}$ & $25.0 \pm 2.9^{\mathrm{deA}}$ & $38.3 \pm 4.4^{\mathrm{fA}}$ & 11.0 & 24.6 & 0.000 \\
\hline BbSr-1 & $10.0 \pm 2.9^{\mathrm{bcdec}}$ & $30.0 \pm 2.9^{\mathrm{abcBC}}$ & $48.3 \pm 7.3^{\mathrm{abcdB}}$ & $81.7 \pm 3.8^{\mathrm{abA}}$ & 11.0 & 46.0 & 0.000 \\
\hline BbKr-1 & $18.3 \pm 1.7^{\mathrm{abcdc}}$ & $31.7 \pm 3.3^{\mathrm{abcc}}$ & $46.7 \pm 3.3^{\mathrm{abcdeB}}$ & $68.3 \pm 3.3^{\mathrm{bcdA}}$ & 11.0 & 50.9 & 0.000 \\
\hline BbDs-2 & $28.3 \pm 4.4^{\mathrm{aC}}$ & $46.7 \pm 3.3^{\mathrm{aBC}}$ & $58.3 \pm 6.7^{\mathrm{abB}}$ & $91.7 \pm 6.0^{\mathrm{aA}}$ & 11.0 & 25.6 & 0.000 \\
\hline BbMg-1 & $16.7 \pm 4.4^{\mathrm{abcdec}}$ & $30.0 \pm 2.9^{\mathrm{abcBC}}$ & $40.0 \pm 5.8^{\text {bcdeB }}$ & $70.0 \pm 2.9^{\mathrm{bcA}}$ & 11.0 & 29.6 & 0.000 \\
\hline BbMg-2 & $26.7 \pm 3.3^{\mathrm{abD}}$ & $41.7 \pm 1.7^{\mathrm{ac}}$ & $61.7 \pm 1.7^{\mathrm{abB}}$ & $93.3 \pm 4.4^{\mathrm{aA}}$ & 11.0 & 92.0 & 0.000 \\
\hline BbMp-1 & $21.7 \pm 6.0^{\mathrm{abcD}}$ & $45.0 \pm 5.8^{\mathrm{aC}}$ & $68.3 \pm 4.4^{\mathrm{aB}}$ & $96.7 \pm 1.7^{\mathrm{aA}}$ & 11.0 & 45.0 & 0.000 \\
\hline BbGp-1 & $5.0 \pm 2.9^{\text {cdec }}$ & $18.3 \pm 1.7^{\mathrm{bcdBC}}$ & $45.0 \pm 10.0^{\mathrm{abcdeB}}$ & $81.7 \pm 6.7^{\mathrm{abA}}$ & 11.0 & 29.4 & 0.000 \\
\hline BbKI-1 & $16.7 \pm 3.3^{\mathrm{abcdec}}$ & $33.3 \pm 4.4^{\mathrm{abc}}$ & $55.0 \pm 5.8^{\mathrm{abB}}$ & $85.0 \pm 2.9^{\mathrm{abA}}$ & 11.0 & 48.3 & 0.000 \\
\hline df & 41 & 41 & 41 & 41 & & & \\
\hline $\mathrm{F}$ & 9.0 & 17.9 & 8.1 & 27.0 & & & \\
\hline$P$ & 0.000 & 0.000 & 0.000 & 0.000 & & & \\
\hline
\end{tabular}

*In a single-dose trial, all the isolates were tested at a concentration of $1 \times 10^{7}$ conidia $/ \mathrm{ml}$

** Means in a column followed by the same lowercase letter are not significantly different, and means in a row followed by the same uppercase letter are not significantly different (Tukey's HSD test; $P<0.05$ )

Table 5 Percentage mortalities of 0-48-h-old adults of Leptinotarsa decemlineata in response to the tested Beauveria bassiana isolates at 3, 5, 7, and 9 days after treatment under laboratory conditions

\begin{tabular}{|c|c|c|c|c|c|c|c|}
\hline \multirow{2}{*}{$\begin{array}{l}\text { Isolate } \\
\text { name }\end{array}$} & \multicolumn{4}{|c|}{ Percent mortality $\left( \pm\right.$ SE) from a single-dose trial ${ }^{*}$} & \multirow[t]{2}{*}{ df } & \multirow[t]{2}{*}{$F$} & \multirow[t]{2}{*}{$P$} \\
\hline & 3 days & 5 days & 7 days & 9 days & & & \\
\hline $\mathrm{BbKm}-1$ & $0.0 \pm 0.0^{\mathrm{aB} * *}$ & $6.7 \pm 3.3^{\mathrm{cdB}}$ & $13.3 \pm 3.3^{\mathrm{bB}}$ & $36.7 \pm 8.8^{\mathrm{eA}}$ & 11 & 10.2 & 0.004 \\
\hline BbKm-2 & $0.0 \pm 0.0^{\mathrm{aC}}$ & $16.7 \pm 3.3^{\mathrm{abcdBC}}$ & $26.7 \pm 6.7^{\mathrm{abAB}}$ & $40.0 \pm 0.0^{\mathrm{deA}}$ & 11 & 20.5 & 0.000 \\
\hline $\mathrm{BbDm}-1$ & $6.7 \pm 3.3^{\mathrm{ac}}$ & $33.3 \pm 3.3^{\mathrm{aB}}$ & $43.3 \pm 6.7^{\mathrm{abB}}$ & $93.3 \pm 3.3^{\mathrm{abA}}$ & 11 & 67.6 & 0.000 \\
\hline $\mathrm{BbFn-3}$ & $0.0 \pm 0.0^{\mathrm{aC}}$ & $3.3 \pm 3.3^{\mathrm{dBC}}$ & $13.3 \pm 3.3^{\mathrm{bB}}$ & $46.7 \pm 3.3^{\mathrm{deA}}$ & 11 & 54.6 & 0.000 \\
\hline BbKp-1 & $3.3 \pm 3.3^{\mathrm{aB}}$ & $10.0 \pm 5.8^{\mathrm{bcdB}}$ & $23.3 \pm 8.8^{\mathrm{abAB}}$ & $53.3 \pm 8.8^{\text {cdeA }}$ & 11 & 9.8 & 0.005 \\
\hline BbAk-1 & $0.0 \pm 0.0^{\mathrm{aC}}$ & $3.3 \pm 3.3^{\mathrm{dC}}$ & $26.7 \pm 3.3^{\mathrm{abB}}$ & $56.7 \pm 6.7^{\text {cdeA }}$ & 11 & 41.1 & 0.000 \\
\hline $\mathrm{BbSr}-1$ & $10.0 \pm 5.8^{\mathrm{aB}}$ & $13.3 \pm 8.8^{\mathrm{abcdB}}$ & $30.0 \pm 10.0^{\mathrm{abB}}$ & $76.7 \pm 6.7^{\mathrm{abcA}}$ & 11 & 14.8 & 0.001 \\
\hline BbKr-1 & $3.3 \pm 3.3^{\mathrm{aB}}$ & $10.0 \pm 5.8^{\mathrm{bcdB}}$ & $20.0 \pm 5.8^{\mathrm{abB}}$ & $80.0 \pm 0.0^{\mathrm{abcA}}$ & 11 & 63.4 & 0.000 \\
\hline BbDs-2 & $10.0 \pm 5.8^{\mathrm{aC}}$ & $26.7 \pm 3.3^{\mathrm{abcBC}}$ & $46.7 \pm 8.8^{\mathrm{aB}}$ & $96.7 \pm 3.3^{\mathrm{aA}}$ & 11 & 42.3 & 0.000 \\
\hline BbMg-1 & $3.3 \pm 3.3^{\mathrm{aB}}$ & $16.7 \pm 3.3^{\mathrm{abcdB}}$ & $20.0 \pm 0.0^{\mathrm{abAB}}$ & $36.7 \pm 6.7^{\mathrm{A}}$ & 11 & 11.3 & 0.003 \\
\hline BbMg-2 & $16.7 \pm 3.3^{\mathrm{aB}}$ & $30.0 \pm 0.0^{\mathrm{abB}}$ & $36.7 \pm 8.8^{\mathrm{abB}}$ & $93.3 \pm 3.3^{\mathrm{abA}}$ & 11 & 45.7 & 0.000 \\
\hline BbMp-1 & $10.0 \pm 5.8^{\mathrm{aB}}$ & $26.7 \pm 3.3^{\mathrm{abcc}}$ & $50.0 \pm 0.0^{\mathrm{aB}}$ & $93.3 \pm 6.7^{\mathrm{abA}}$ & 11 & 58.8 & 0.000 \\
\hline BbGp-1 & $3.3 \pm 3.3^{\mathrm{aB}}$ & $10.0 \pm 5.8^{\mathrm{bcdB}}$ & $23.3 \pm 6.7^{\mathrm{abB}}$ & $66.7 \pm 8.8^{\mathrm{bcdA}}$ & 11 & 19.4 & 0.000 \\
\hline BbKI-1 & $0.0 \pm 0.0^{\mathrm{aC}}$ & $6.7 \pm 3.3^{\mathrm{cdc}}$ & $30.0 \pm 5.8^{\mathrm{abB}}$ & $80.0 \pm 0.0^{\mathrm{abcA}}$ & 11 & 118.3 & 0.000 \\
\hline$d f$ & 41 & 41 & 41 & 41 & & & \\
\hline $\mathrm{F}$ & 2.2 & 5.1 & 3.3 & 15.7 & & & \\
\hline$P$ & 0.035 & 0.000 & 0.004 & 0.000 & & & \\
\hline
\end{tabular}

*In a single-dose trial, all the isolates were tested at a concentration of $1 \times 10^{7}$ conidia $/ \mathrm{ml}$

**Means in a column followed by the same lowercase letter are not significantly different, and means in a row followed by the same uppercase letter are not significantly different (Tukey's HSD test; $P<0.05$ ) 
Table 6 GenBank nucleotide accessions of tested Beauveria bassiana isolates along with other Beauveria species based on ITS region used for phylogenetic analysis

\begin{tabular}{|c|c|c|c|c|}
\hline Strain/isolates & Accession no. & Strain/isolates & Species & Accession no. \\
\hline BbKm-1 & MT441868 & TF6-1B & B. bassiana & $J X 122736.1$ \\
\hline BbKm-2 & MT441869 & $\mathrm{EABb} 04 / 01$ & B. bassiana & DQ364698.1 \\
\hline $\mathrm{BbDm}-1$ & MT441872 & CGAIPFBS-012 & B. bassiana & KY495188.1 \\
\hline BbFn-3 & MT441875 & IISR-EPF-04 & B. bassiana & KU363833.1 \\
\hline BbKp-1 & MT441877 & 2718 & B. bassiana & KU364353.1 \\
\hline BbAk-1 & MT441881 & HHWG1 & B. brongniartii & JX110385.1 \\
\hline $\mathrm{BbSr}-1$ & MT441882 & SASRI & B. brongniartii & JX110388.1 \\
\hline $\mathrm{BbKr}-1$ & MT441871 & ARSEF 2641 & B. amorpha & HQ880808.1 \\
\hline BbDs-2 & MT441879 & B518a & B. amorpha & HQ880806.1 \\
\hline BbMg-1 & MT441883 & BYYC-05 & B. asiatica & MG345071.1 \\
\hline BbMg-2 & MT441884 & BUB824 & B. asiatica & MG642836.1 \\
\hline BbMp-1 & MT441880 & FUM03 & B. varroae & MF667767.1 \\
\hline BbGp-1 & MT441886 & B5 & B. varroae & MH374536.1 \\
\hline $\mathrm{BbKl}-1$ & MT441885 & ARSEF 4622 & B. australis & HQ880790.1 \\
\hline F19-N & MG640376.1 & ARSEF 4598 & B. australis & HQ880789.1 \\
\hline MG562497 & MG562497.1 & F585 & B. caledonica & DQ529233.1 \\
\hline SHU.M.161 & KU158472.1 & $\mathrm{BG} 47$ & B. caledonica & MT180427.1 \\
\hline SHU.M.131 & KU158461.1 & 1717 & B. vermiconia & FJ973063.1 \\
\hline EABb04 & KC753382.1 & ARSEF 7281 & B. sungii & HQ880815.1 \\
\hline SASRI BB444 & JX110368.1 & EFCC 5657 & B. sungii & JX463219.1 \\
\hline
\end{tabular}

and larval mortalities are in agreement with those reported by Todorova et al. (2000) and Ozturk et al. (2015).

As for the phylogenetic placement of tested B. bassiana isolates, the results demonstrated that all the $B$. bassiana isolates tested had 99\% evolutionary homology with other $B$. bassiana isolates from the NCBI database. In a previous study, Sayed et al. (2018) investigated the genetic difference of $11 \mathrm{~B}$. bassiana isolates from the Taif region of Saudi Arabia by sequencing based on the ITS and COI regions and found genetic differences among the 4 isolates tested. In another study, Gürlek et al. (2018) defined and characterized the molecular phylogenetic diversity of 40 fungus isolates including Beauveria spp. and Metarhizium spp. using Bloc and B-tubulin gene regions, and they determined that there was a close relationship among the isolates examined. Dhar et al. (2019) performed phylogenetic analysis of 13 B. bassiana isolates from India by comparative RAPD-PCR amplification with 10 different RAPD primers. They found that 3 of them were closely related each other. Zhang et al. (2020) examined the genetic difference among B. bassiana isolates from different hosts by phylogenetic analysis and determined genetic differences between the virulent isolates. In a more recent study, Gasmi et al. (2021) characterized the variety of genes involved in diverse mechanisms of the infective cycle of 42 isolates that have different thermo-tolerance, growth rates, and virulence. The analyzed genes showed general genetic diversity measured as and copy number variation (CNV) and non-synonymous changes (NSC) with most of them being subjected to positive episodic diversifying selection. Correlation analyses between NSC or CNV and the isolate growth rate, thermo-tolerance, and virulence revealed that various genes shaped the biological features of the fungus. ITS1/ITS4 primers, which are used to reproduce the ITS region that is one of the general diagnosis primers in fungi, are widely used in the diagnosis of EPF in the world (Fergani and Yehia 2020). Therefore, it was used in molecular identification of fungi isolated in this study. The similarity value in the dendrogram drawn at the highest Boot Strap value (Select distribute test) (1000 replicates), using ITS gene regions in GenBank with all B. bassiana isolates tested in this study varied around $99 \%$.

\section{Conclusion}

This study demonstrated that indigenous isolates of $B$. bassiana were pathogenic to different stages of $\mathrm{CPB}$ under laboratory conditions. However, 4 isolates (BbDm-1, BbDs-2, BbMg-2, and BbMp-1) were more pathogenic than others. Further studies are however needed to evaluate the efficacy of $B$. bassiana isolates on $\mathrm{CPB}$ under field conditions. 


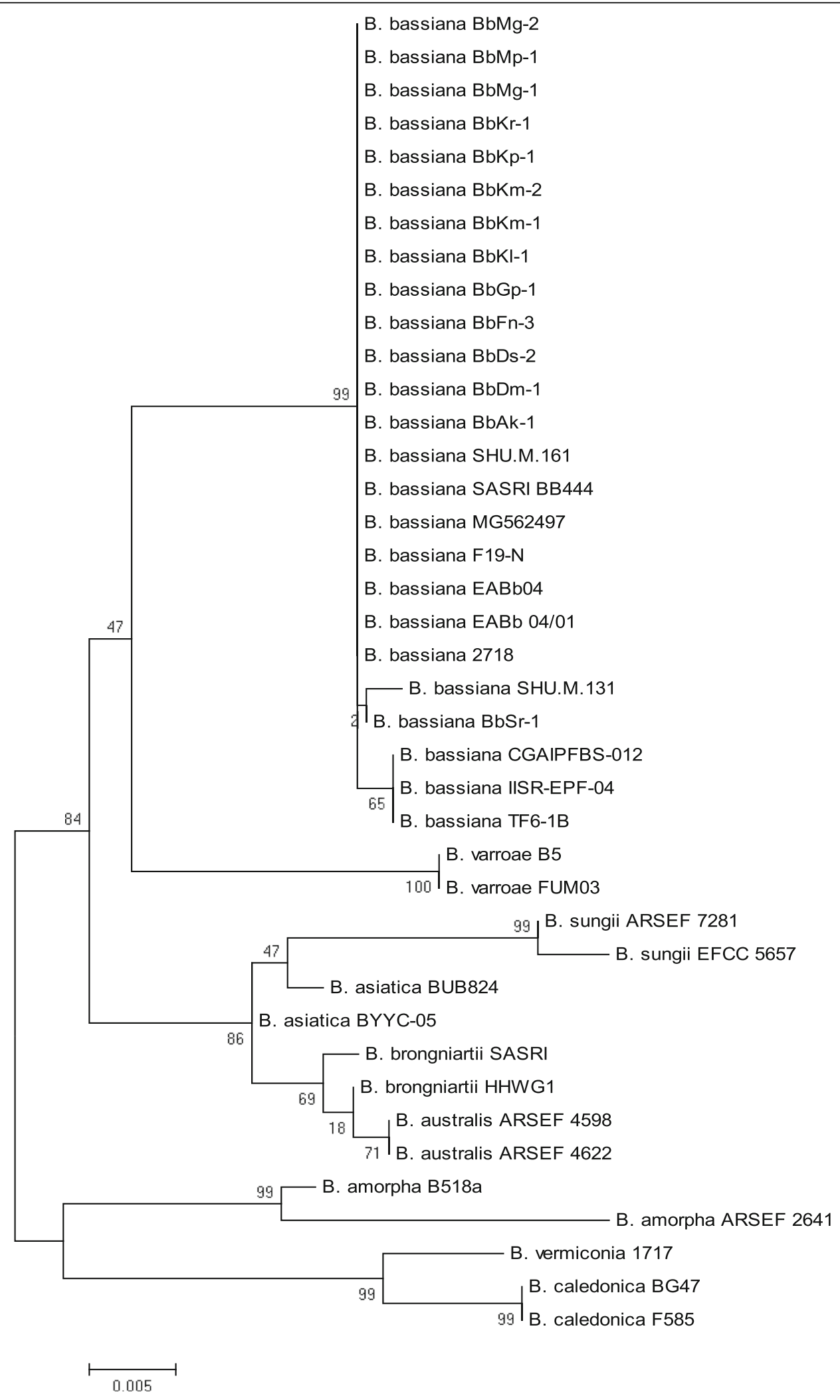

Fig. 1 Maximum likelihood tree based on the Tamura 3-parameter model showing the phylogenetic relationship between the tested Beauveria bassiana isolates and other Beauveria isolates from GenBank based on ITS region sequence 


\section{Abbreviations}

IPM: Integrated pest management; $\mathrm{RH}$ : Relative humidity; EPF: Entomopathogenic fungi; PCR: Polymerase chain reaction; CTAB: Cetyltrimethylammonium bromide; NCBI: National Center for Biotechnology Information

\section{Acknowledgements}

The authors thank to the Scientific Projects Coordination Unit of Akdeniz University (Antalya, Turkey) for financially supporting the study (Project no.: BAP FDK-2019-4859)

\section{Authors' contributions}

DB and HST substantially contributed to the conception and design of the article. Data curation and analysis were maintained by HST. Writing the entire manuscript was done by FE. The authors have read, revised, and approved the manuscript.

\section{Funding}

This study was funded by the Scientific Projects Coordination Unit (SPCU) of Akdeniz University (Antalya, Turkey) under grant number BAP FDK-2019-4859. The SPCU provided fund for collecting samples and buying chemicals for experiments and supported experimental facilities to carry out experiments.

\section{Availability of data and materials}

All data generated or analyzed in this study are available in this published manuscript.

\section{Declarations}

Ethics approval and consent to participate

Not applicable.

\section{Consent for publication}

Not applicable.

\section{Competing interests}

The authors declare that they have no conflict of interest.

\section{Author details}

${ }^{1}$ Antalya Directorate of Agricultural Quarantine, Ministry of Agriculture and Forestry, Antalya, Turkey. ${ }^{2}$ Faculty of Agriculture, Department of Plant Protection, Akdeniz University, 07070 Antalya, Turkey.

Received: 14 January 2021 Accepted: 17 March 2021

Published online: 22 March 2021

\section{References}

Altschul SF, Madden TL, Schaffer AA, Zhang J, Zhang Z, Miller W, Lipman DJ (1997) Gapped BLAST and PSI-BLAST: a new generation of protein database search programs. Nucleic Acids Res 25(17):3389-3402. https://doi.org/10.1 093/nar/25.17.3389

Atak U (1973) Studies on the morphology, bio-ecology and control methods of potato beetle (Leptinotarsa decemlineata Say.) in the Thrace Region. Turkish Ministry of Agriculture General Directorate of Plant Protection and Agricultural Quarantine Publications. Tech Bull 6:63

Boiteau G, LeBlanc J-PR (1992) Colorado potato beetle life stages. Agriculture Canada Publication, Ottawa

CABI (2017) Leptinotarsa decemlineata (Colorado potato beetle) data sheet. In: Invasive species compendium. CAB International, Wallingford http://www.ca bi.org/isc/datasheet/30380. Accessed 25 Nov 2020

Campbell RK, Anderson TE, Semel M, Roberts DW (1985) Management of the Colorado potato beetle using the entomogenous fungus Beauveria bassiana. Am Potato J 62(1):29-37. https://doi.org/10.1007/BF02871297

Casagrande RA (1987) The Colorado potato beetle: 125 years of mismanagement. Bull Entomol Soc Am 33(3):142-150. https://doi.org/10.1093/besa/33.3.142

Dhar S, Jindal V, Jariyal M, Gupta V (2019) Molecular characterization of new isolates of the entomopathogenic fungus Beauveria bassiana and their efficacy against the tobacco caterpillar, Spodoptera litura (Fabricius) (Lepidoptera: Noctuidae). Egypt J Biol Pest Control 29(1):8. https://doi.org/1 0.1186/s41938-019-0110-3

Doyle JJ, Doyle JL (1990) Isolation of plant DNA from fresh tissue. Focus 12:13-15
Fancelli M, Dias AB, Delalibera IJ, Cerqueira De Jesus S, Souza Do Nascimento A, Oliveira e Silva S (2013) Beauveria bassiana strains for biological control of Cosmopolites sordidus (Germ.) (Coleoptera: Curculionidae) in plantain. BioMed Res Int. https://doi.org/10.1155/2013/184756

FAOSTAT (2019) Food and agriculture data. http://www.fao.org/faostat/en. Accessed 22 Nov 2020

Fargues J (1991) Fecundity and egg fertility in the adult Colorado beetle (Leptinotarsa decemlineata) surviving larval infection by the fungus Beauveria bassiana. Entomol Exp Appl 61(1):45-51. https://doi.org/10.1111/j.1570-7458.1 991.tb02394.x

Fergani YA, Yehia RS (2020) Isolation, molecular characterization of indigenous Beauveria bassiana isolate, using ITS-5.8 s rDNA region and its efficacy against the greatest wax moth, Galleria mellonella L. (Lepidoptera: Pyralidae) as a model insect. Egypt J Biol Pest Control 30:96

Gasmi L, Baek S, Kim JC, Kim S, Lee MR, Park SE, Shin TY, Lee SJ, Parker BL, Kim JS (2021) Gene diversity explains variation in biological features of insect killing fungus, Beauveria bassiana. Sci Rep 11(1):91. https://doi.org/10.1038/s41598020-78910-1

Goettel MS, Inglis GD (1997) Fungi. In: Fungi hyphomycetes: manual of techniques in insect pathology. Academic Press, San Diego, pp 213-248

Gürlek S, Sevim A, Sezgin FM, Sevim E (2018) Isolation and characterization of Beauveria and Metarhizium spp. from walnut fields and their pathogenicity against the codling moth, Cydia pomonella (L.) (Lepidoptera: Tortricidae). Egypt J Biol Pest Control 28:50

Hall TA (1999) BioEdit: A user-friendly biological sequence alignment editor and analysis program for Windows 95/98NT. Nucleic Acids Symp Ser 41:95-98

Ignoffo CM, Garcia C, Kroha M, Samisinakova A, Kalalova S (1983) A leaf surface treatment bioassay for determining the activity of conidia of Beauveria bassiana against Leptinotarsa decemlineata. J Invertebr Pathol 41(3):385-386. https://doi.org/10.1016/0022-2011(83)90257-4

Jacques RL, Fasulo TR (2015) Colorado potato beetle Leptinotarsa decemlineata. DPI Entomology Circular 271. Florida Department of Agriculture and Consumer Services, Division of Plant Industry and University of Florida. http:// entnemdept.ufledu/creatures/veg/leaf/potato. Accessed 26 Nov 2020.

Keskin C, Yorulmaz-Salman S (2020) Deltamethrin and imidacloprid resistance levels of Leptinotarsa decemlineata (Coleoptera: Chrysomelidae) populations collected from Afyonkarahisar, Turkey. Turkish J Eng 2(1):1-5

Kimura M (1980) A simple method for estimating evolutionary rate of base substitutions through comparative studies of nucleotide sequences. J Mol Evol 16(2):111-120. https://doi.org/10.1007/BF01731581

Long DW, Drummond FA, Groden E (1998) Susceptibility of Colorado potato beetle (Leptinotarsa decemlineata) eggs to Beauveria bassiana. J Invertebr Pathol 71(2):182-183. https://doi.org/10.1006/jipa.1997.4714

Mahr DL, Whitaker P, Ridgway NM (2008) Biological control of insects and mites: an introduction to beneficial natural enemies and their use in pest management. University of Wisconsin Cooperative Extension, No. A3842.

Niezgodzinski P, Koroluk L (1976) Biometric measurements of the width of the head capsule of different developmental phases of the Colorado beetle larvae Leptinotarsa decemlineata (Say) [Coleoptera: Chrysomelidae]. Bull Entomol Pologne 46:559-561

Ozturk HE, Guven O, Karaca I (2015) Effects of some bioinsecticides and entomopathogenic fungi on Colorado potato beetle (Leptinotarsa decemlineata L.). Comm Appl Biol Sci Ghent Univ 80(2):205-211

Roberts DW, LeBrun RA, Semel M (1981) Control of the Colorado potato beetle with fungi. In: Lashomb JH, Casagrande RA (eds) Advances in Potato Pest Management. Hutchinson Ross Publ. Co., Stroudsburg, pp 119-137

Sayed SM, Ali EF, El-Arnaouty SA, Samy FM, Sayed AA (2018) Isolation, identification, and molecular diversity of indigenous isolates of Beauveria bassiana from Taif region, Saudi Arabia. Egypt J Biol Pest Control 28(1):47. https://doi.org/10.1186/s41938-018-0054-z

Tamura K, Peterson D, Peterson N, Stecher G, Nei M, Kumar S (2011) MEGA5: molecular evolutionary genetics analysis using maximum likelihood, evolutionary distance, and maximum parsimony methods. Mol Biol Evol 28(10):2731-2739. https://doi.org/10.1093/molbev/msr121

Thompson JD, Higgins DG, Gibson TJ (1994) CLUSTAL W: improving the sensitivity of progressive multiple sequence alignment through sequence weighting, positions-specific gap penalties and weight matrix choice. Nucleic Acids Res 22(22):4673-4680. https://doi.org/10.1093/nar/22.22.4 673

Timonin MI (1939) Pathogenicity of Beauveria bassiana (Bals.) Vuill. on Colorado potato beetle larvae. Can J Res 17:103-107 
Todorova SI, Coderre D, Côté JC (2000) Pathogenicity of Beauveria bassiana isolates toward Leptinotarsa decemlineata (Coleoptera: Chrysomelidae), Myzus persicae (Homoptera: Aphididae) and their predator Coleomegilla maculata lengi (Coleoptera: Coccinellidae). Phytoprotection 81:15-22

Watt BA, Lebrun RA (1984) Soil effects of Beauveria bassiana on pupal populations of the Colorado potato beetle (Coleoptera: Chrysomelidae). Environ Entomol 13(1):15-18. https://doi.org/10.1093/ee/13.1.15

White TJ, Bruns T, Lee S, Taylor JW (1990) Amplification and direct sequencing of fungal ribosomal RNA genes for phylogenetics. In: PCR Protocols: A Guide to Methods and Applications. Academic Press, New York, pp 315-322

Zhang Z, Lu Y, Xu W, Sui L, Du Q, Wang Y, Zhao Y, Li Q (2020) Influence of genetic diversity of seventeen Beauveria bassiana isolates from different hosts on virulence by comparative genomics. BMC Genomics 21(1):451. https://doi.org/10.1186/s12864-020-06791-9

\section{Publisher's Note}

Springer Nature remains neutral with regard to jurisdictional claims in published maps and institutional affiliations.

\section{Submit your manuscript to a SpringerOpen ${ }^{\circ}$ journal and benefit from:}

- Convenient online submission

- Rigorous peer review

- Open access: articles freely available online

- High visibility within the field

- Retaining the copyright to your article

Submit your next manuscript at $\boldsymbol{\nabla}$ springeropen.com 